изводить тщательное изсльвованіе сердпа во всякомъ нопдаюпемся ему случа'b беременности. При наличшости сьүженія венознаго отверстія до б-го шьсяца беременности раціональнье всего шрибъгать къ искусственному выкидышу. Если первые признаки сердечнаго страданія обнаруживаются на 6-мъ мЂсяцђ, то плод'ь обыкновенно не пережниваетъ посльднихъ мъсяцевъ беременности. Дыти матерей, страдающихъ сердечнымш пороками, виобще обречены на непродолжительную вньутробную жизнь пли бывають поражены различными цороками развитія. При наступленіп колляпса у беременныхъ и роженицъ, авторъ приб́ыгаетъ къ осторожному црим'ьенію хлороформа (sic) до обпаруженія его возбуждающаго дыйствія; хлороформъ не только ведетъ къ немедленному улучшенію состоянія больной, но и облегчаетъ возможность всякихъ дальньйішихъ акушерскихт м'ропріятій. $F$. $W$. Ross утверждаетъ, чт0 ошасность выкидыша сердечныхъ больныхъ такъ же велика, какъ п ошасность срочныхъ родовъ, такъ какъ порокъ сердца является .весьма серьознымъ осложненіемъ какой-бы то ни было родовой дьятельности. $T$. W. Higgins, наоборотъ, того мньнія, что шоздніе мъсяцы беременности гораздо болье ошасны, такъ какь сердечные пороки у беременныхь прогрессирують съ каждынь шъсяцемъ и замьтно истощають больныхъ; возбужденіе искусственныхъ родовъ даеть тьмъ болье благопріятное шрезсказапіе, чьыъ лучше общее состояніе сердечныхъ больныхъ. Fo/n Cronyn обращаеть вниманіе на то, что хлороформъ щри сердечнонь колляпсь, дыйствительно показанъ, такъ какъ онъ уменьшаеть крайнюю раздражительность и возбужденность сердца, и этим' именно дыйствуеть благопріятно. Онъ особенно предостерегаетъ отъ прнмъненія наперстянки у беременныхъ. $S$. F. Armstrong привель случай одной женщины, страдающей съуженіемъ венознаго отверстіп и благополучно родивіпеї 5-хъ дытей, находящихся въ вождылленномъ здравіи.

\title{
B. Каплянскій.
}

\section{A. Mars. Przypadek porodu u osoby cieapiacej na wade serca.} (Przeglad lekarski, 1893, 추 11). Случай родовъ у сездечной больной.

N. N.21-го года, первобеременная, страдаетъ недостаточностью двустворчатаго клапана. Натиная съ 3-го мьсяца беременности припадки со стороны сердца, а именно одыпка и сильныйлее сердцебіеніе, становилиьь все болье и болье грозными. С' теченіемъ беременности состояніе больної, не смотря на всь терапевтическія пьропріятія, все болье ухудшалось; мальйшее двшженіе больной вызывало у нея мучительную одышку п сердцебіеніе. Устуная настойчивому желанію больной, рышено было выжидать до конца беременности. Въ 9-м'ъ мъсяц'ь беременности въ состояніш больной, внезапно и вопреки всякпмъ ожиданіямъ, стало замьчаться значительное и все прогрессирующее улучшепіе, а именно по мьрь опусканія дна матки и вступленія головки плода въ малый тазъ. 0на могла даже расхаживать по комнать безъ всякой одышки и сердцебіенія. 12-го ноября 1892, въ 1 часъ дня начались роды. Раскрытіс маточной шейки уже приближалось къ концу; ни къ 9-ти часам'ь вечера потүги стали частыми, болъзненными, родовой акть пере- 
сталь подвигаться впередъ, пульсъ малый, частый (112), общее безпокойство и возбужденность. Дано внутрь 15 капель t-rae strophant. Авторь pbшилъ окончпть роды щитцами, расширивъ предварительно внутреннее маточное устье баллономъ Braun'a, и, въ крайнемъ случађ, надрњзываніемъ краевъ ostii interni. Желал успокоить общее раздраженное состояніе и сдылать потуги болье рвдкими, авторъ далъ больної внутрь 10 капель $t$-rae opii simplicis Благодаря послфднеи, больная не только успокоилась и начала засыпать въ шромежуткахъ между потугами, сдылавшшися болье рьдкими, но и роды неожиданно, вновь нагали подвигаться впередъ, благодаря усиленію и больпей дыйствительвости потугъ. Чрезъ часъ з'въ добровольно раскрылся впо.Інь, и посль разрыва пузыря головка вступила во влагалище. Во 2-мъ період' родовъ роженица снова стала жаловаться на боли въ грудной кльтккь, наступила синюха, одышка, пульсъ частый (130), едва ощутимый. Јюэтому авторъ поспжшиль окончить роды щипцами, и извлекъ жпвую, донопенную дывочку высомъ въ 4000 grm. 3-ій періодъ р0довъ и послњродовое теченіе нормальны. Размьры сердца съ каждымъ днешъ уменьшались: во время беременности сердечная тупость доходила до праваго края грудины, чрезъ нысколько дней посль родовъ сердце не выстукивалось за ея львымъ краемъ. Систолическій шумъ надъ верхушкой выслушивался по прежнему. 0писанный случай выдвигаетъ на видъ одно обстоятельство, на которое до сихъ порь никто не обратиль должнаго вниманія, а пменно значительное улучшеніе грозныхъ припадковъ у сердечныхъ больныхъ въ 9-мъ мьсяц' беременности, вполды объяснимое опусканіемъ дна матки и вступленіень головки младенца въ малый тазъ, особенно у первородящихч. ЦБлесообразность прим'ненія анестезирующихъ средствъ во время родовъ, не смотря на сердечные пороки, обыкновенно служащіе непреложнымъ противупоказаніемъ къ ихъ употребденію, извьстна уже многимъ (сп. статью д-ра L. F. Lusk'a: «Mitral Stenosis in pregnancy», реферированную въ этомъ жүрналь). Данный случай намъ показываетъ, что еще лүчше и безопаснье, чьыъ хлороформъ, дњйствуетъ въ подобныхъ случаяхъ опій.

В. Каплянскій.

74. F. Westemark. Experimentelle Untersuchungen uber die Wehenthätigkeit des menschlichen Uterus bei der physiologischen Geburt. (Skandinavisches Arch. für:Physiologie. 1893).Потужная дьятельность человьчесной матки при физіологическихъ родахъ. Экспериментальное изсльдованіе.

Статья Westermark'а разд'ьляется на пять главъ съ историческимъ введеніемъ. Въ носльвдемъ питируются работы Schatz'a '), Poullet ${ }^{2}$ ), Polaillon ${ }^{3}$ ), Acconci ${ }^{4}$ ), Döhnhoff'a ${ }^{5}$ ).

1) Arch. f. Gynäk. 1872. Bd. III, стр. 58.

2) Archives de Tocologie. Fevrier 1880.

3) Arch. de Physiologie 1880, cтp. 1.

4) Sulla contrazione e sull'inerzia dell'utero, Torino 1891.

$\left.{ }^{5}\right)$ Arch. f. Gynäk. 1892. B. XLII, стр. 305. 